\title{
3 Research Square

\section{Bioremidation of Spirulina Plantesis Against Deltamethrin Mediated Toxicity and Its Chemical Residues in Chicken Meat}

\section{Samar Saber Ibrahim}

Benha University Faculty of Veterinary Medicine

\section{Rasha Elsabagh}

Benha University Faculty of Veterinary Medicine

\section{Ali Allam}

Benha University Faculty of Veterinary Medicine

Gehan Youssef

Benha University Faculty of Veterinary Medicine

\section{Sabreen Ezzat Fadl}

Matrouh university

\section{Ehab Yahya Abdelhiee}

Matrouh University

\section{Mohamed Alkafafy}

Taif University College of Science

\section{Ahmed Soliman}

Cairo University Faculty of Veterinary Medicine

Mohamed Aboubakr ( $\square$ mohamed.aboubakr@fvtm.bu.edu.eg )

Benha University Faculty of Veterinary Medicine https://orcid.org/0000-0003-1719-4844

\section{Research Article}

Keywords: Spirulina, Deltamethrin, Oxidative stress, Chicken, Meat, Residues

Posted Date: April 20th, 2021

DOI: https://doi.org/10.21203/rs.3.rs-407177/v1

License: (c) (1) This work is licensed under a Creative Commons Attribution 4.0 International License. Read Full License 


\section{Abstract}

Deltamethrin (DM) is a synthetic pyrethroid insecticide commonly used in veterinary and agriculture. However, both animal and human exposure is associated with hepatorenal toxicity. Our experimental goal was to assess the protective effects of Spirulina plantesis (SP) against DM-induced hepato-renal injury, growth performance, meat chemical composition and its residues in meat, liver and skin of broiler chickens. Sixty one-day-old Cobb broiler chicks were assigned to 4 experimental groups, each was divided into 3 replicates with five chicks each; $1^{\text {st }}$ group received basal diet alone (Control), $2^{\text {nd }}$ group supplemented with SP $20 \mathrm{~g} / \mathrm{kg}$ diet, $3^{\text {rd }}$ group supplemented with DM $300 \mathrm{mg} / \mathrm{kg}$ diet, and $4^{\text {th }}$ group supplemented with DM and SP diet. All groups were received the treatment for 35 days. DM, decreased body weight, weight gain, and increased feed conversion rate. DM showed significant increase in ALT, AST, urea, creatinine and MDA and significant decrease in SOD, and GSH levels. Also, significant decrease in DM levels in meat, skin, and liver by SP with a reduction \% 63.01, 63.00 and $62.90 \%$ in meat, skin and liver, respectively. The DM intoxicated group showed significant decrease in protein and significant increase in fat, cholesterol and triglycerides when compared to control group. Histopathological changes were also recorded. Dietary SP improved these parameters parameters. Dietary inclusion of SP can be recommended due to the protective effects on DM induced toxicity in broiler chickens.

\section{Introduction}

By 2050, the demand for animal protein will increase. Chicken meat has been identified as a major product and an effective source of protein (Chia et al. 2019; Elahi et al. 2020). Pesticide use has increased in recent decades and leads to contamination of food (Cabrera 2017) and potentially toxic components in humans, which may cause serious health problems (Azam et al. 2020).

Pyrethroids residues in meat may cause malformations, immune injuries and lymphoadenopathy to the consumers (Anne-Marie et al. 2015; Tang et al. 2018). Because of its insecticidal properties, deltamethrin (DM) is one of the most commonly used pyrethroids. Despite this, deltamethin causes serious degrees of toxicity, oxidative stress (Lu et al. 2019), and lipid damage (Saoudi et al. 2017). This makes chemical safety a growing concern for consumers (Meurillon et al. 2018). Pesticide disposal strategies have been examined in recent decades to improve consumer food safety (Azam et al. 2020).

Spirulina platensis (SP) considered to be economically natural resources food ingredients capable of promoting animal growth and improving their meat quality (Barros de Medeiros et al. 2021). Micro-algae rich in nutrients of interest to foods such as antioxidants, vitamins, minerals, polysaccharides, essential amino acids, proteins, and fats (Bhuvana et al. 2019; Santhakumaran et al. 2020). These compounds increased the feed digestibility, nutritional, technical, meat quality and immunological response (Diaz et al. 2017; De Tonnac et al. 2018; Kibria and kim 2019). So it's a promising addition to poultry diets (ElHady and El Ghalid 2018). 
Therefore, the main aim of this study was to evaluate the bioremediation role of SP as a feed supplement for broiler chicken against DM effect on body weight gain, feed conversion rate, hepatorenal toxicity, meat chemical composition and its residues in meat, liver and skin.

\section{Materials And Methods}

\section{Chemicals}

DM (Butox ${ }^{\circledR} 50 \mathrm{mg} / \mathrm{ml}$; Intervet Co., France) for veterinary use, while SP was purchased as a powder from HerbaForce Co., UK.

\section{Experimental broiler chicks}

Sixty, one-day-old Cobb broiler chicks (El-Wataniya Poultry Company, Egypt). Chicks were assigned to 4 experimental groups, each was divided into 3 replicates with five chicks each; $1^{\text {st }}$ group received basal diet alone (Control), $2^{\text {nd }}$ group supplemented with SP $20 \mathrm{~g} / \mathrm{kg}$ diet (Mirzaie et al. 2018), $3^{\text {rd }}$ group supplemented with DM $300 \mathrm{mg} / \mathrm{kg}$ diet (Chardra et al. 2013), and $4^{\text {th }}$ group supplemented with DM and SP diet. All groups were received the treatment for 35 days. In separate units, chicks were housed under hygienic conditions on the floor with free access to feed and water. The starting temperature of $32^{\circ} \mathrm{C}$ was reduced by $2^{\circ} \mathrm{C}$ each week. Table 1 illustrates how the diet was designed as a starter and finisher to satisfy the nutritional requirements. The chicks were vaccinated according to the vaccination program. This study was approved by the Ethical Committee of the Faculty of Veterinary Medicine, Benha University, (BUFVTM 06-03-21).

\section{Growth parameters:}

Daily feed intake and gain in body weight were calculated. FCR was calculated after the end of the experiment (total feed consumed divided by a total weight gain).

\section{Blood samples}

Blood samples were collected via wing vein from all chickens in each group after the end of the experiment (35 days), in clean, dry tubes and it was left in a slope position to clot at the room temperature. After blood centrifugation at $2000 \mathrm{~g}$ for $10 \mathrm{~min}$, serum samples were obtained and it was kept frozen at $-20^{\circ} \mathrm{C}$ until further use in biochemical analysis.

\section{Serum biochemical analysis:}

Sera were used for estimation of liver (ALT, AST) and renal injury biomarkers (creatnine, urea) using commercial kits (Biodiagnostic Co., Egypt).

\section{Detection of oxidative cascade indices:}


The tissues (liver, kidney) was dissected and washed with a phosphate buffered saline solution ( $\mathrm{pH} 7.4)$ containing heparin to remove any clots or red blood cells. One gram of each tissue was homogenized in buffer ( $5 \mathrm{ml})$, using homogenizer. Tissue homogenates was centrifuged at $4000 \mathrm{rpm}$ for $20 \mathrm{~min}$, then stored at $-20^{\circ} \mathrm{C}$. Oxidative status was done by determination of Glutathione (GSH) level, malondialdehyde (MDA) level and superoxide dismutase (SOD) were evaluated using commercial kits (Biodiagnostic Co., Egypt).

\section{Evaluation of meat chemical composition:}

Protein and fat content of chicken's meat samples were estimated as described by Anderson (2007). Cholesterol and triglycerides were evaluated spectrophotometrically at wavelength $578 \mathrm{~nm}$ (Rifal et al. 1999).

\section{HPLC Evaluation for DM residues in meat, skin and liver:}

DM residues in meat, skin, and liver were evaluated using HPLC. Samples were extracted and examined according to Cheng et al. (2009) using DM standards (PESTANAL, $99.8 \%$ purity). The DM calibration curve was estimated by different dilutions of solution in methanol at $4^{\circ} \mathrm{C}$ at concentrations of $1,5,10,20$, 40 , and $80 \mu \mathrm{g} / \mathrm{kg}$, spiking samples were at $5,10,20,40$, and $80 \mu \mathrm{g} / \mathrm{kg}$ and kept before extraction for 30 minutes.

HPLC; Agilent Series 1200 quaternary gradient pump with HPLC 2D Chemstation software (Agilent -

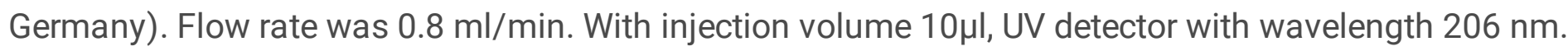
Mobile phase using Isocratic mode methanol: water (90\%: 10\%). Analytical column was a reversed-phase column Column C18 $(250 * 4.6 \mathrm{~mm}, 5 \mu \mathrm{m})$ Teknorama. While, Solid-phase extraction (SPE) columns (Bond Elut C18 (500 mg, $3 \mathrm{~mL}$; Varian, Les Ulis, France). HLB Oasis cartridges ( $200 \mathrm{mg}, 6 \mathrm{ml}$ was obtained from the waters "Milford, MA, USA". Syringe filters (A $0.45 \mathrm{~mm}$ disposable membrane filter was purchased from Cronus Filter) (UK).

\section{Histopathological examination:}

Samples from liver, kidney and intestine were collected from slaughtered chickens and prepared according to Banchroft et al. (1996).

\section{Statistical Analysis:}

The results (mean $\pm S E$ ) were analyzed using one-way ANOVA, then to determine the differences between the averages; Duncan's test was applied. Statistical Package for Social Science software (SPSS (20) software (SPSS Inc., Chicago, USA) was used.

\section{Results}

Effect on on growth performance parameters: 
Broiler chickens exposed to DM, revealed significant reduction in BW, BWG, and an increase in FCR. SP treated group showed an increase in BW, BWG, and decrease in FCR. DM+SP treated group showed an improvement in growth performance compared to control group (Table 2).

\section{Effect on liver markers (ALT, AST) and kidney markers (Urea, Creatnine):}

Serum of broiler chicken exposed to DM showed significant increase in ALT, AST, urea and creatinine. Non-significant changes were recorded in SP treated group in relation to control group. While serum of broiler chicken treated with DM + SP group showed significant decrease in ALT, AST, urea, and creatinine when compared to DM treated group (Table 3).

\section{Effect on oxidative cascade indices in liver and kidney tissues:}

Homogenate of liver and kidney tissues of DM treated group showed a significant increase in MDA and significant decrease in SOD, and GSH levels. Also, SP treated group showed non-significant change when compared to control group. While, DM + SP treated group showed significant decrease in MDA and significant increase in SOD, and GSH levels when compared to DM treated (Table 4).

\section{HPLC evaluation of DM residues in meat, liver and skin of broiler chickens:}

DM failed to be detected in non-intoxicated groups (control and those fed SP alone). There was a significant difference between groups intoxicated with DM and those treated with DM+SP. Results in table (5) and figure (1) revealed a significant decrease in DM levels in meat, skin, and liver by SP with a reduction percentage $63.01,63.00$ and $62.90 \%$ in meat, skin and liver, respectively.

\section{Effect on Meat chemical composition (protein, Fat, Cholesterol and Triglycerides):}

SP in poultry diet has a direct effect on protein, fat, cholesterol and triglycerides in meat. It also decreases DM toxic effect on meat as shown in Table (6). Meat chemical composition of the group fed with SP showed an increase in protein and significant decrease in fat, cholesterol and triglycerides when compared to control group. While, meat samples in the DM intoxicated group showed significant decrease in protein and significant reduction in fat, cholesterol and triglycerides when compared to control group. Moreover, it was found that meat samples from DM+SP treated group revealed a an increase in protein and lowering fat, cholesterol and TG when compared to DM treated group.

\section{Effect on histopathological characters of liver, kidney and intestine:}

Liver of control, SP treated groups (Figure 2 A, B) exhibited normal histological structure of hepatic lobules. DM (Figure $2 \mathrm{C}$ ), revealed vacuolation of hepatocytes located near the hepatic capsule and around the terminal hepatic venules. Pyknotic and lyric changes of hepatocytic nuclei were seen. Multiple focal necrotic areas scatter all hepatic parenchyma and hyperplasia of Kupffer cells were seen grade (4). $\mathrm{DM}+\mathrm{SP}$ (Figure 2 D) showed ballooning degeneration especially in the centrolobular zone of hepatocytes. 
Fewest number of intracellular fat droplets were noticed. Kupffer cell hyperplasia and of hepatic sinusoids narrowing was also seen grade (III).

Kidney of control, SP treated (Figure 3 A, B) groups revealed normal histological structure. DM (Figure 3 C), revealed enlargement of the renal glomeruli and an increase of the mesangium matrix. Epithelial cell degeneration was recorded in the renal tubules and tubular epithelial lining showed marked swelling and alumnus and cellular casts leds to narrowing and occlusion of the tubular lumen. Tubular epithelial cells showed necrosis and apoptosis $<50 \%$ (score 3 ). DM+SP (Figure $3 \mathrm{D}$ ) revealed enlargement of some renal glomeruli and an increase of the mesangium matrix. The renal tubular epithelial lining showed degeneration (swelling and granularity of its cytoplasm). Albuminous eosinophilic casts were seen intratubular. Cell necrosis and apoptosis $<25 \%$ was seen in tubular epithelial (score 2 ).

Histological section of a jejunum segment of control and SP treated groups (Figure 4 A, B) showed normal histological structure of villus mucosa which characterized by intact epithelial lining with goblet cells in-between. DM (Figure 4 C), revealed widening and hyperplasia of intestinal crypts score (2). The intestinal villi showed sloughing of its epithelial lining and necrosis of villus tips with fusion of some intestinal villi and atrophy of some villi score (2). The intestinal lumen contained desquamated epithelial cells and thickened mucosal lamina propria by inflammatory cells, mainly lymphocytes and macrophages score (2). DM+SP (Figure 4 D) showed limited improvement of histological picture. Intestinal crypts showed hyperplasia of its epithelial lining score (1). Intestinal villi revealed few numbers of desquamated epithelial lining and mild to moderate atrophy score (1). The intestinal lumen contained desquamated epithelial cells and thickened mucosal lamina propria by inflammatory cells score (1).

\section{Discussion}

Since DM is widely used as an insecticide, its effect on the human health and the environment has become a significant concern (Sibiya et al. 2019). DM induced histological changes in various organs. DM was metabolized in the liver; toxic DM metabolites have been found in various tissues, including, liver, brain, fat and muscles (Abdelkhalek et al. 2015).

In the current experiment, DM supplementation to broiler chicken, elicted toxicological effects in different tissues; which was reported through biochemical, residual effect on chicken meat, liver and skin and its effect on chicken meat quality and the hisopathological investigations. SP supplementation provided a bioremediation role.

Regarding to the effect of DM on the body weight our result revealed that there are significant decreases in the body weight of DM treated group compared to control and SP treated groups. This study mentioned that an increase in growth performance in $S P$ treated group. Previous studies have indicated that SP supplementation has a positive impact on poultry growth (Khan et al. 2020; Pestana et al. 2020; Alwaleed et al. 2021). It was also reported that the amino acid profile of SP may be superior to other plant foods (Evans et al. 2015). Additionally, SP contains physiologically active substances such as carotenoid pigments, polyunsaturated fatty acid, phycocyanin, vitamins, micro-minerals, and macroelements 
(Becker 2007). These compounds have potent antimicrobial, anti-inflammatory, immune enhancers and antioxidant properties (Abdel-Daim et al. 2013). So, the physiological functions and chemical composition of SP were involved in metabolism related to growth efficiency, and might be the primary cause of BWG and FCR improvement in broiler chickens. The decrease in BW of DM treated group can be as a result of lower feed conversion efficiency. The DM+SP treatment group showed an improvement in body weight gain, which demonstrated the beneficial effects of SP on the total body weight gain of chicks fed with DM with SP. In poultry ration, the excessive proliferation of saprophytic bacteria leads to the release of various metabolites that could increase the toxicity of DM in form of depressing growth rate (Chandra et al. 2013). When compared to control chickens, SP supplementation increased body weight gain. While the body weight of broilers decreased significantly in the DM-only group, it increased significantly in the DM-plus-SP group.

Regarding to the effect of DM on hepatorenal tissue our result showed that there are significant increases in ALT, AST, Urea and Creatnine in serum of DM treated group when compared with control and SP+DM treated group. When comparing the DM treated group to the control and SP+DM treated groups, MDA levels increased significantly while SOD and GSH levels decreased in both hepatic and renal tissues. The hepato-renal injuries induced by DM were attributed to oxidative stress which caused by free radical production. DM has been shown to increase ROS production in the rat liver and kidney (Abdel-Daim et al. 2016). Also, oxidative stress was detected in Nile tilapia after DM exposure (Abdelkhalek et al. 2015).

$\mathrm{SP}$ is a type of blue, green algae that contains all essential AAs as well as the pigments phycocyanin (strengthens immunity) and chlorophyll (helps with detoxification) (El-Tantawy 2015). SP is well-known for its high nutritional value and a strong hepatic and renal protective activity; it also has an important function in many toxicitiy studies (Mazokopakis et al. 2014). SP administration decreased serum hepatic and renal injury biomarkers and lowered lipid peroxidation in tissues. SP's antioxidant and protective properties were due to the presence of antioxidant active constituents such as minerals, vitamins, proteins, carbohydrates, lipids, b-carotene, and C-phycocyanins, (Upasani and Balaraman 2003).

Nowadays, Food safety becomes a major concern. Chemical contamination of meat with pesticide residues causes adverse impacts on human health. In this study, meat, skin, and liver samples were evaluated for DM residues. As, pyrethroids are lipophilic in nature and precipitate into fatty tissues, therefore, the main target organ is fat for surveillance purposes (Stefanelli et al. 2009). It was found that the higher DM residual levels were in skin followed by liver and meat. This may be due to that skin of poultry (rich in fat), liver also tend to form fat deposition (Martín-Castillo et al., 2010). Accumulation of pyrethroids in the mammals body fat caused acute poisoning in humans (skin, respiratory, gastrointestinal, and neurological symptoms; Hudson et al. 2014).

Despite that the persistence of pyrethroids in the environment not exceed 90 days, long-term exposure leads to toxic effects on the cardiovascular, genetic, immune and nervous systems, teratogenic, carcinogenic and mutagenic effects (Ma 2009: Koureas et al. 2012). Moreover, they affect male reproductive function (Saillenfait et al. 2015). In order to protect consumers, Maximum Residue Levels 
(MRLs) in food have been established. FDA (2003) limits the maximum residue of DM in foods of animal origin by $30 \mathrm{ng} / \mathrm{g}$ to protect human health. Moreover, The European Union, Commission Regulation (EU) (2017) regulates DM Maximum residues limits in avians with $100 \mu \mathrm{g} / \mathrm{kg}$ fat. DM is one of the most toxic pyrethroids. Decontamination of them enhances food safety (Bhilwadikar et al. 2019). So, there is a crucial need for evaluate effective, sustainable, and environment-friendly pesticide removal practices (Azam et al. 2020). In this study, SP lowered DM residues with reduction percentages $63.01,63.00$ and $62.90 \%$ in meat, skin and liver, respectively. This agrees with Abdel-Daim et al. (2016) who normalize toxic effects of DM in mice by SP. In recent decades, Poultry meat consumption has increased. As, it is an important source of protein of growing concern worldwide (Daghir et al. 2020).

Concerning the effect of DM and \or SP on meat chemical composition. It was found that the meat chemical composition in the group fed with SP displayed a large rise in protein while decreasing in fat, cholesterol, and triglycerides when compared to control group. While, meat samples in the DM-intoxicated group had a substantial decrease in protein but an increase in fat, cholesterol, and TG when compared to control group. Moreover, it was found that meat samples from a DM+SP treated group revealed a significant increase in protein and significant decrease in fat, cholesterol and TG. Results revealed that intoxication with DM caused an increase in fat, cholesterol and TG. A decrease in protein levels in intoxicated groups has been detected. The higher fat content in tissues, the greater amount of pyrethroids. There is a strong association between lipid content and pyrethroid levels in beef and fish, while chicken samples show a mean correlation, may be due to chickens are slaughtered at an earlier age (Dallegrave et al. 2018).

DM toxicity causes oxidative stress in poultry that directly affect th chemical composition of meat. Although, few studies evaluated DM toxicity on proteins, oxidative stress directly damages proteins and amino acids (Fedorova et al. 2014). While, SP suppresses oxidative stress (Mahmoud et al. 2021) this may counteract the action of DM on meat chemical composition. Moreover, SP promotes benefits to growth and enhance meat quality (Barros de Medeiros et al. 2021). It also enhances chicken flavor in the meats (Altmann et al. 2020). As, It supplements poultry with protein, polysaccharides, amino acids, lipids, polyunsaturated fatty acids, minerals, vitamins, phenolics and antioxidants (Bhuvana et al. 2019; Santhakumaran et al. 2020). It also increases the antioxidant capacity of chicken meat (Pestana et al. 2020). It increases nutritional value (higher lipid and protein contents), improved meat fatty acid profile (Roohani et al. 2019).

The histological findings (liver, kidneys, and intestine) in SP treated group were similar to those of the control group revealed that SP did not cause any adverse effects on the chicken tissues examined. DM in chickens showed disrupted hepatic, renal and intestinal architecture. Thus, changes in histopathology could be caused by the production of ROS, which causes damage to various tissues (Abdel-Daim et al. 2016a). Previous studies on DM exposure in experimental animals agreed with our results (Abdou and Abdel-Daim 2014; El Golli-Bennour et al. 2019; Han et al. 2020). DM+SP improved the histopathological findings, as reported in previous studies (Abdel-Daim et al. 2016a,b). 


\section{Conclusion}

The role of oxidative stress in DM toxicity in broiler chickens is critical. Antioxidants have been shown to be effective in preventing the toxicity caused by DM. DM toxicity resulted in varying degrees of lipid peroxidation, suppression of antioxidant enzymes' and glutathione function, and changes in serum biochemical parameters in this study. In terms of serum and tissue biochemical changes, antioxidant activity, and oxidative stress, SP supplementation provided nearly complete protection. It causes a marked decrease in DM residues in meat, skin and liver. Moreover, enhances chemical composition of meat.

\section{Declarations}

\section{Ethics approval}

This study was approved by the Ethical Committee of the Faculty of Veterinary Medicine, Benha University, (BUFVTM 06-03-21).

\section{Consent to Participate}

All authors interpreted the data and approved the final version.

\section{Consent for publication}

- The manuscript is not previously published in the same or very similar form in other

- The manuscript is not currently under consideration in other journals

\section{Authors' contribution}

Ibrahim SS, Elsabagh R, performed the residues of DM. Allam A, Youssef G, Alkafafy M, Soliman A and Aboubakr M; contributed in the study design, experimental work and statistical analysis and writing the manuscript. Fadl SE, Abdelhiee EY and Ahmed Abdeen analyzed the sera and tissue samples. All authors interpreted the data and approved the final version.

\section{Funding}

Taif University Researchers Supporting Project number (TURSP-2020/57), Taif University, P.O. Box 11099, Taif 21944, Saudi Arabia.

\section{Conflicts of Interest}

The authors have indicated that they have no conflict of interest regarding the content of this article.

\section{Data Availability}

All relevant data are within the paper. 


\section{References}

1. Abdel-Daim M, El-Bialy BE, Rahman HG, Radi AM, Hefny HA, Hassan AM (2016a): Antagonistic effects of Spirulina platensis against sub-acute deltamethrin toxicity in mice: Biochemical and histopathological studies. Biomedicine \& Pharmacotherapy 77, 79-85.

2. Abdel-Daim MM, Abuzead SM, Halawa SM (2013): Protective role of Spirulina platensis against acute deltamethrin-induced toxicity in rats. PLoS One. 8(9):e72991. doi: 10.1371/journal.pone.0072991.

3. Abdel-Daim M, El-Bialy BE, Rahman HG, RadiAM, Hefny HA, Hassan AM (2016b): Antagonistic effects of Spirulina platensis against subacute deltamethrin toxicity in mice: biochemical and histopathological studies. Biomediine \& Pharmacotherapy 77, 79-85.

4. Abdelkhalek NK, Ghazy EW, Abdel-Daim MM (2015): Pharmacodynamic interaction of Spirulina platensis and deltamethrin in freshwater fish Nile tilapia, Oreochromis niloticus: impact on lipid peroxidation and oxidative stress. Environmental Science and Pollution Research 22, 3023-3031.

5. Abdou RH, Abdel-Daim MM (2014): Alpha-lipoic acid improves acute deltamethrin-induced toxicity in rats. Canadian Journal of Physiology and Pharmacology 92, 773-779.

6. Altmann BA, Wigger R, Ciulu M, Morlein D (2020): The effect of insect or microalga alternative protein feeds on broiler meat quality. Journal of the Science of Food and Agriculture 100, 4292-4302.

7. Alwaleed EA, El-Sheekh M, Abdel-Daim MM, Saber H (2021): Effects of Spirulina platensis and Amphora coffeaeformis as dietary supplements on blood biochemical parameters, intestinal microbial population, and productive performance in broiler chickens. Environmental Science and Pollution Research 28, 1801-1811.

8. Anne-Marie S, Dieynaba N, Jean-Philippe S (2015): Pyrethroids: Exposure and health effects - An update. International Journal of Hygiene and Environmental Health, 218, 281-292.

9. Anderson $S$ (2007): Determination of fat, moisture, and protein in meat and meat products by using the FOSS FoodScan Near-Infrared Spectrophotometer with FOSS Artificial Neural Network Calibration Model and Associated Database: collaborative study. Journal of AOAC International 90, 1073-1083.

10. Azam SMR, Maa H, Xua B, Devic S, Siddiqued MAB, Stanleye SL, Bhandarif B, Zhua J (2020): Efficacy of ultrasound treatment in the removal of pesticide residues from fresh vegetables: A review. Trends in Food Science \& Technology 97, 417-432.

11. Banchroft JD, Stevens A, Turner DR (1996): Theory and practice of histological techniques. Churchil Livingstone, New York, London, San Francisco, Tokyo, $4^{\text {th }} \mathrm{Ed}$

12. Barros de Medeiros VP, Pimentel TC, Sant'Ana AS, Magnani M (2021): Microalgae in the meat processing chain: feed for animal production or source of techno-functional ingredients. Current Opinion in Food Science 40, 125-134.

13. Becker EW (2007): Micro-algae as a source of protein. Biotechnology Advances 25, 207-210. 
14. Bhilwadikar T, Pounraj S, Manivannan S, Rastogi NK., Negi PS (2019): Decontamination of microorganisms and pesticides from fresh fruits and vegetables: A comprehensive review from common household processes to modern techniques. Comprehensive Reviews in Food Science and Food Safety 18, 1003-1038.

15. Bhuvana P, Sangeetha P, Anuradha V, Syed Ali M (2019): Spectral characterization of bioactive compounds from microalgae: N. oculata and C. vulgaris. Biocatalysis and Agricultural Biotechnology 19:101094. https://doi.org/10.1016/j.bcab.2019.101094.

16. Cabrera LY (2017): Pesticides. Cambridge Quarterly of Healthcare Ethics 26, 602-615.

17. Chandra N, Jain NK, Sondhia S, Srivastava AB (2013): Deltamethrin induced toxicity and ameliorative effect of Alpha Tocopherol in broilers. Bulletin of Environmental Contamination and Toxicology 90, $673-678$.

18. Cheng J, Liu M, Yu Y, Wang X, Zhang H, Ding L, Jin H ( 2009): Determination of pyrethroids in porcine tissues by matrix solid-phase dispersion extraction and high-performance liquid chromatography. Meat Science 82, 407-412.

19. Chia SY, Tanga CM, Van Loon JJA, Dicke M (2019): Insects for sustainable animal feed: inclusive business models involving smallholder farmers. Current Opinion in Environmental Sustainability 41, 23-30.

20. Daghir, N., Diab-El-Harake, M., Kharroubi, S., 2020. Poultry production and its effects on food security in the mena region. Journal of Applied Poultry Research 30, 100110. https://doi.org/10.1016/j.japr.2020.10.009.

21. Dallegrave A, Pizzolato TM, Barreto F, Bica VC, Eljarrat E, Barceló D (2018): Residue of insecticides in foodstuff and dietary exposure assessment of Brazilian citizens. Food and Chemical Toxicology 115, 329-335.

22. De Tonnac A, Guillevic M, Mourot J (2018): Fatty acid composition of several muscles and adipose tissues of pigs fed n-3 PUFA rich diets. Meat Science 140, 1-8.

23. Diaz MT, Perez C, Sanchez Cl, Lauzurica S, Caneque V, Gonzalez C, De La Fuente J (2017): Feeding microalgae increases omega 3 fatty acids of fat deposits and muscles in light lambs. Journal of Food Composition and Analysis 56, 115-123.

24. El Golli-Bennour E, Timoumi R, Annaibi E, Mokni M, Omezzine A, Bacha H, Abid-Essefi S (2019): Protective effects of kefir against deltamethrin-induced hepatotoxicity in rats. Environmental Science and Pollution Research 26, 18856-18865.

25. Elahi U, Ma YB, Wu SG, Wang J, Zhang HJ, Qi GH (2020): Growth performance, carcass characteristics, meat quality and serum profile of broiler chicks fed on housefly maggot meal as a replacement of soybean meal. Journal of Animal Physiology and Animal Nutrition 104, 1075-1084.

26. El-Hady AMA, El-Ghalid OAH (2018): Spirulina platensis Algae (SPA): a novel poultry feed additive. Effect of SPA supplementation in broiler chicken diets on productive performance, lipid profile and calcium-phosphorus metabolism. Worlds Poultry Science Journal 7498, 1-7. 
27. El-Tantawy WH (2015): Antioxidant effects of Spirulina supplement against lead acetate-induced hepatic injury in rats, Journal of Traditional and Complementary Medicine 6, 327-331.

28. Evans AM, Smith DL, Moritz JS (2015): Effects of algae incorporation into broiler starter diet formulations on nutrient digestibility and 3 to $21 \mathrm{~d}$ bird performance. Journal of Applied Poultry Research 24, 206-214.

29. FDA (Food and Drug Administration) of the United States (2003). Pesticide tolerances.

30. Fedorova M, Bollineni RC, Hoffmann R (2014) Protein carbonylation as a major hallmark of oxidative damage: update of analytical strategies. Mass Spectrometry Reviews 33, 79-97.

31. Han B, Lv Z, Zhang X, Lv Y, Li S, Wu P, Yang Q, Li J, Qu B, Zhang Z (2020): Deltamethrin induces liver fibrosis in quails via activation of the TGF- $\beta 1 /$ Smad signaling pathway. Environmental Pollution 259, 113870. doi: 10.1016/j.envpol.2019.113870.

32. Hudson NL, Kasner EJ, Beckman J, Mehler L, Schwartz A, Higgins S, Bonnar-Prado J, Lackovic M, Mulay P, Mitchell Y, Larios L, Walker R, Waltz J, Moraga-McHaley S, Roisman R, Calvert GM (2014): Characteristics and magnitude of acute pesticide-related illnesses and injuries associated with pyrethrin and pyrethroid exposures-11 states, 2000-2008. American Journal of Indstrial Medicne 57, 15-30.

33. Khan S, Mobashar M, Mahsood FK, Javaid S, Abdel-Wareth AA, Ammanullah H, Mahmood A 2020. Spirulina inclusion levels in a broiler ration: evaluation of growth performance, gut integrity, and immunity. Tropical Animal Health and Production 52, 3233-3240.

34. Kibria S, Kim IH (2019): Impacts of dietary microalgae (Schizochytrium JB5) on growth performance, blood profiles, apparent total tract digestibility, and ileal nutrient digestibility in weaning pigs. Journal of the Science of Food and Agriculture 99, 6084-6088.

35. Koureas M, Tsakalof A, Tsatsakis A, Hadjichristodoulou C (2012): Systematic review of biomonitoring studies to determine the association between exposure to organophosphorus and pyrethroid insecticides and human health outcomes. Toxicological Letters 210, 155-168.

36. Lu Q, Sun Y, Ares I, Anadón A, Martínez M ,Martínez-Larrañaga M-R, Yuan Z, Wang X, Martínez M-A (2019): Deltamethrin toxicity: A review of oxidative stress and metabolism. Environmental Research $170,260-281$.

37. $\mathrm{Ma} X$ (2009): Research progress on analytical technique of pyrethroid pesticide residue. Journal of Anhui Agricultural Sciences, 28, 13775-13777.

38. Mahmoud YI, Shehata AMM, Fares NH, Mahmoud AA (2021): Spirulina inhibits hepatocellular carcinoma through activating $\mathrm{p} 53$ and apoptosis and suppressing oxidative stress and angiogenesis. Life Sciences 265, 118827. https://doi.org/10.1016/j.Ifs.2020.118827

39. Martín-Castillo A, Castells MT, Adanez G, Polo MT, Perez BG, Ayala I (2010): Effect of atorvastatin and diet on non-alcoholic fatty liver disease activity score in hyperlipidemic chickens. Biomedicine \& Pharmacotherapy 64, 275-281.

40. Mazokopakis EE, Starakis IK, Papadomanolaki MG, Mavroeidi NG, Ganotakis ES (2014): The hypolipidaemic effects of Spirulina (Arthrospira platensis) supplementation in a Cretan population: a 
prospective study $94,432-437$.

41. Meurillon M, Ratel J, Engel E (2018): How to secure the meat chain against toxicants?. Innovative Food Science and Emerging Technologies. 46, 74-82.

42. Mirzaie S, Zirak-Khattab F, Hosseini SA, Darian HD (2018): Effects of diatary Spirulina on antioxidant status, lipids profile, immune response and performance characteristics of broiler chicken reared under high ambient temperature. Asian-Australasian Journal of Animal Sciences 31, 556-563.

43. Pestana JM, Puerta B, Santos H, Madeira MS, Alfaia CM, Lopes PA, Pinto RMA, Lemos JPC, Fontes CMGA, Lordelo MM, Prates JAM (2020): Impact of dietary incorporation of Spirulina (Arthrospira platensis) and exogenous enzymes on broiler performance, carcass traits, and meat quality. Poultry Science 99, 2519-2532.

44. Rifal N, Bachorik PS, Albers JJ (1999): Lipids, Lipoproteins and apolipoproteins in Burits CA, Ashwood ER, editors. Tietz. Text book of clinical chemistery. $3^{\text {rd }}$ ed. Philladelphia: W. B. Saunders company P: 806-61

45. Roohani AM, Abedian Kenari A, Fallahi Kapoorchali M, Borani MS, Zoriezahra SJ, Smiley AH, Esmaeili M, Rombenso AN (2019): Effect of spirulina Spirulina platensis as a complementary ingredient to reduce dietary fish meal on the growth performance, wholebody composition, fatty acid and amino acid profiles, and pigmentation of Caspian brown trout (Salmo trutta caspius) juvenil. Aquaculture Nutrition 25, 633-645

46. Saillenfait AM, Ndiaye D, Sabaté JP (2015): Pyrethroids: exposure and health effects - an update. International Journal of Hygiene and Environmental Health 218, 281-292.

47. Santhakumaran P, Ayyappan SM, Ray JG (2020): Nutraceutical applications of twenty-five species of rapid-growing green microalgae as indicated by their antibacterial, antioxidant and mineral content. Algal Research 47, 101878.

48. Saoudi M, Badraoui R, Bouhajja H, Ncir M, Rahmouni F, Grati M, Jamoussi K, El Feki A (2017): Deltamethrin induced oxidative stress in kidney and brain of rats: protective effect of Artemisia campestris essential oil. Biomedicine Pharmacotherapy 94, 955-963.

49. Sibiya I, Poma G, Cuykx M, Covaci A, Daso AP, Okonkwo J (2019): Targeted and non-target screening of persistent organic pollutants and organophosphorous flame retardants in leachate and sediment from land fill sites in Gauteng Province, South Africa. Science of the Total Environment 653, 12311239.

50. Stefanelli P, Santilio A, Cataldi L, Dommarco R (2009): Multiresidue analysis of organochlorine and pyrethroid pesticides in ground beef meat by gas chromatographymass spectrometry. Jounal of Environmental Science and Health B 44, 350-356.

51. Tang W, Wang D, Wang J, Wu Z, Li L, Huang M, Xu S, Yan D (2018): Pyrethroid pesticide residues in the global environment: An overview. Chemosphere, 191, 990-1007.

52. The European Union, Commission Regulation (EU) EU -Pesticides Database, (2017) (available at http://eceuropaeu/food/plant/ pesticides/eu-pesticides- database/public/? event=homepage\&language $=\mathrm{EN}$ 
53. Upasani CD, Balaraman R (2003): Protective effect of Spirulina on lead induced deleterious changes in the lipid peroxidation and endogenous antioxidants in rats. Phytotherapy Research 17, 330-334.

\section{Tables}

Table 1: The formulation of the basal diet for broilers.

\begin{tabular}{|lll|}
\hline Ingredients kg/100 kg & $\begin{array}{l}\text { Starter diet } \\
(0 \text { to 21 days) }\end{array}$ & $\begin{array}{l}\text { Finisher diet } \\
(22-35 \text { days })\end{array}$ \\
\hline Yellow corn & 58.57 & 64 \\
\hline Soyabean meal (48\%) & 32 & 25 \\
\hline Corn gluten (60\%) & 5 & 5 \\
\hline Soybean oil & 0.7 & 2.5 \\
\hline Di-calcium phosphate (22\%Ca\&19\%Ph) & 1.5 & 0.95 \\
\hline Lime stone (35\% ca) & 1.7 & 1.74 \\
\hline Common salts & 0.2 & 0.15 \\
\hline Methionine (95\%) & 0.13 & 0.36 \\
\hline Lysine (98\%) & 0 & 0.1 \\
\hline Vitamins and mineral premix ${ }^{* *}$ & 0.2 & 0.2 \\
\hline Calculated compostion & & \\
\hline Protein (\%) & 23 & 20 \\
\hline k. calory ME/kg & 2950 & 3120 \\
\hline Calcium (\%) & 1 & 0.9 \\
\hline Phosphorus (\%) & 0.48 & 0.35 \\
\hline
\end{tabular}

** Each $2 \mathrm{~kg}$ contains the following vitamins and minerals:

Vit. A 12 MIU, Vit. $D_{3} 2$ MIU, Vit. E 1000 mg, Vit. $k_{3} 1000$ mg, Vit. B 1000 mg, Vit. B 5000 mg, Vit. B 1500 $\mathrm{mg}$, Vit. $B_{12} 10 \mathrm{mg}$, biotin $50 \mathrm{mg}$, pantothinic acid $10 \mathrm{~g}$, nicotinic acid $30 \mathrm{~g}$, folic acid $1000 \mathrm{mg}$, manganese $60 \mathrm{~g}$, zinc $50 \mathrm{~g}$, iron $30 \mathrm{~g}$, copper $4 \mathrm{~g}$, iodine $300 \mathrm{mg}$, selenium $100 \mathrm{mg}$, cobalt $100 \mathrm{mg}$, carrier $\left(\mathrm{CaCO}_{3}\right)$ to $3 \mathrm{~kg}$. (Premix- Agrivet Pharm, Egypt). 
Table 2: Effect of DM and/or SP on growth performance parameters in broiler chickens $(n=15)$.

\begin{tabular}{|lllll|}
\hline Parameters & Control & SP & DM & SP+DM \\
\hline B.wt (7 days) (g) & $143.80 \pm 0.50^{\mathrm{a}}$ & $144.53 \pm 0.86^{\mathrm{a}}$ & $139.27 \pm 0.41^{\mathrm{c}}$ & $141.33 \pm 0.51^{\mathrm{b}}$ \\
B.wt (35 days) (g) & $1938.6 \pm 2.11^{\mathrm{b}}$ & $2137.7 \pm 1.16^{\mathrm{a}}$ & $1526.7 \pm 8.70^{\mathrm{d}}$ & $1773.3 \pm 3.01^{\mathrm{c}}$ \\
Weight gain (g) & $1794.8 \pm 2.28^{\mathrm{b}}$ & $1993.1 \pm 1.50^{\mathrm{a}}$ & $1387.5 \pm 8.76^{\mathrm{d}}$ & $1631.9 \pm 2.93^{\mathrm{c}}$ \\
Feed intake (g) & $3254.3 \pm 2.48^{\mathrm{b}}$ & $3270 \pm 2.73^{\mathrm{a}}$ & $3931.7 \pm 2.63^{\mathrm{d}}$ & $3193.7 \pm 1.09^{\mathrm{c}}$ \\
FCR (\%) & $1.81 \pm 0.002^{\mathrm{c}}$ & $1.64 \pm 0.001^{\mathrm{d}}$ & $2.11 \pm 0.013^{\mathrm{a}}$ & $1.95 \pm 0.003^{\mathrm{b}}$ \\
\hline
\end{tabular}

Table 3: Effect of DM and/or SP on biochemical parameters in broiler chickens $(n=5)$.

\begin{tabular}{|lllll|}
\hline Parameters & Control & SP & DM & SP+DM \\
ALT $(\mathrm{U} / \mathrm{L})$ & $12.24 \pm 1.72^{\mathrm{c}}$ & $10.75 \pm 1.97^{\mathrm{c}}$ & $62.58 \pm 5.17^{\mathrm{a}}$ & $27.19 \pm 3.16^{\mathrm{b}}$ \\
AST $(\mathrm{U} / \mathrm{L})$ & $16.69 \pm 2.35^{\mathrm{c}}$ & $14.65 \pm 2.69^{\mathrm{c}}$ & $85.33 \pm 7.06^{\mathrm{a}}$ & $33.44 \pm 4.31^{\mathrm{b}}$ \\
Urea $(\mathrm{mg} / \mathrm{dl})$ & $11.13 \pm 1.57^{\mathrm{c}}$ & $9.77 \pm 1.79^{\mathrm{c}}$ & $56.89 \pm 4.70^{\mathrm{a}}$ & $21.63 \pm 2.87^{\mathrm{b}}$ \\
Creatinine $(\mathrm{mg} / \mathrm{dl})$ & $0.61 \pm 0.09^{\mathrm{c}}$ & $0.54 \pm 0.10^{\mathrm{c}}$ & $3.13 \pm 0.26^{\mathrm{a}}$ & $1.26 \pm 0.16^{\mathrm{b}}$ \\
\hline
\end{tabular}

Table 4: Effect of DM and/or SP on antioxidant parameters in hepatic and renal tissues of broiler chickens $(n=5)$.

\begin{tabular}{|c|c|c|c|c|c|}
\hline Parameters & Organ & Control & SP & DM & $S P+D M$ \\
\hline $\begin{array}{l}\mathrm{MDA} \\
(\mathrm{nmol} / \mathrm{a})\end{array}$ & Liver & $17.25 \pm 1.42^{\mathrm{C}}$ & $15.14 \pm 1.78^{c}$ & $88.18 \pm 7.29^{a}$ & $34.22 \pm 2.45^{\mathrm{b}}$ \\
\hline $\operatorname{SOD}(U / g)$ & Liver & $3.56 \pm 0.30^{\mathrm{ab}}$ & $4.38 \pm 0.40^{\mathrm{a}}$ & $0.41 \pm 0.01^{\mathrm{c}}$ & $2.62 \pm 0.16^{b}$ \\
\hline $\mathrm{GSH}(\mathrm{mg} / \mathrm{g})$ & $\begin{array}{l}\text { Liver } \\
\text { Kidney }\end{array}$ & $21.37 \pm 1.00^{\mathrm{ab}}$ & $26.26 \pm 1.82^{a}$ & $2.46 \pm 0.07^{c}$ & $12.91 \pm 1.27^{\mathrm{b}}$ \\
\hline $\begin{array}{l}\mathrm{MDA} \\
(\mathrm{nmol} / \mathrm{g})\end{array}$ & Kidney & $14.24 \pm 1.01^{c}$ & $12.50 \pm 1.30^{c}$ & $71.09 \pm 1.67^{a}$ & $48.76 \pm 3.12^{b}$ \\
\hline $\operatorname{SOD}(\mathrm{U} / \mathrm{g})$ & Kidney & $2.34 \pm 0.33^{a b}$ & $2.87 \pm 0.13^{a}$ & $0.27 \pm 0.01^{c}$ & $1.56 \pm 0.14^{b}$ \\
\hline $\mathrm{GSH}(\mathrm{mg} / \mathrm{g})$ & & $17.03 \pm 1.39^{a b}$ & $20.92 \pm 1.84^{a}$ & $1.96 \pm 0.06^{\mathrm{C}}$ & $11.51 \pm 1.01^{\mathrm{b}}$ \\
\hline
\end{tabular}


Table 5: Bioremediation role of SP against DM residues in meat, skin and liver using HPLC $(n=5)$.

\begin{tabular}{|llllll|}
\hline Parameters & Control & SP & DM & SP+DM & $\begin{array}{l}\text { Reduction } \\
(\%)\end{array}$ \\
\hline DM $(\mu \mathrm{g} / \mathrm{kg})$ Meat & $0.00 \pm 0.00^{\mathrm{c}}$ & $0.00 \pm 0.00^{\mathrm{c}}$ & $14.28 \pm 0.62^{\mathrm{a}}$ & $5.28 \pm 0.23^{\mathrm{b}}$ & $63.01 \%$ \\
DM $(\mu \mathrm{g} / \mathrm{kg})$ Skin & $0.00 \pm 0.00^{\mathrm{c}}$ & $0.00 \pm 0.00^{\mathrm{c}}$ & $62.30 \pm 2.72^{\mathrm{a}}$ & $23.05 \pm 1.01^{\mathrm{b}}$ & $63.00 \%$ \\
DM $(\mu \mathrm{g} / \mathrm{kg})$ Liver & $0.00 \pm 0.00^{\mathrm{c}}$ & $0.00 \pm 0.00^{\mathrm{c}}$ & $22.23 \pm 0.97^{\mathrm{a}}$ & $8.25 \pm 0.36^{\mathrm{b}}$ & $62.90 \%$ \\
\hline
\end{tabular}

Table (6) Effect of SP and/or DM on chemical composition of chicken meat ( $n=5)$.

\begin{tabular}{|lllll|}
\hline Parameters & Control & SP & DM & SP+DM \\
Protein $(\% / g)$ & $22.60 \pm 0.09^{\mathrm{b}}$ & $24.66 \pm 0.80^{\mathrm{a}}$ & $9.69 \pm 0.20^{\mathrm{d}}$ & $49.89 \pm 1.54^{\mathrm{c}}$ \\
Fat $(\% / \mathrm{g})$ & $0.36 \pm 0.01^{\mathrm{c}}$ & $0.26 \pm 0.01^{\mathrm{d}}$ & $0.78 \pm 0.02^{\mathrm{a}}$ & $39.82 \pm 1.23^{\mathrm{d}}$ \\
Cholesterol $(\mathrm{mg} / \mathrm{g})$ & $16.08 \pm 0.50^{\mathrm{c}}$ & $12.43 \pm 0.38^{\mathrm{d}}$ & $28.45 \pm 0.88^{\mathrm{a}}$ & $61.61 \pm 2.01^{\mathrm{a}}$ \\
Triglycerides $(\mathrm{mg} / 100 \mathrm{~g})$ & $0.61 \pm 0.09^{\mathrm{c}}$ & $0.54 \pm 0.10^{\mathrm{c}}$ & $21.03 \pm 0.65^{\mathrm{b}}$ & $57.19 \pm 1.77^{\mathrm{b}}$ \\
\hline
\end{tabular}

\section{Figures}



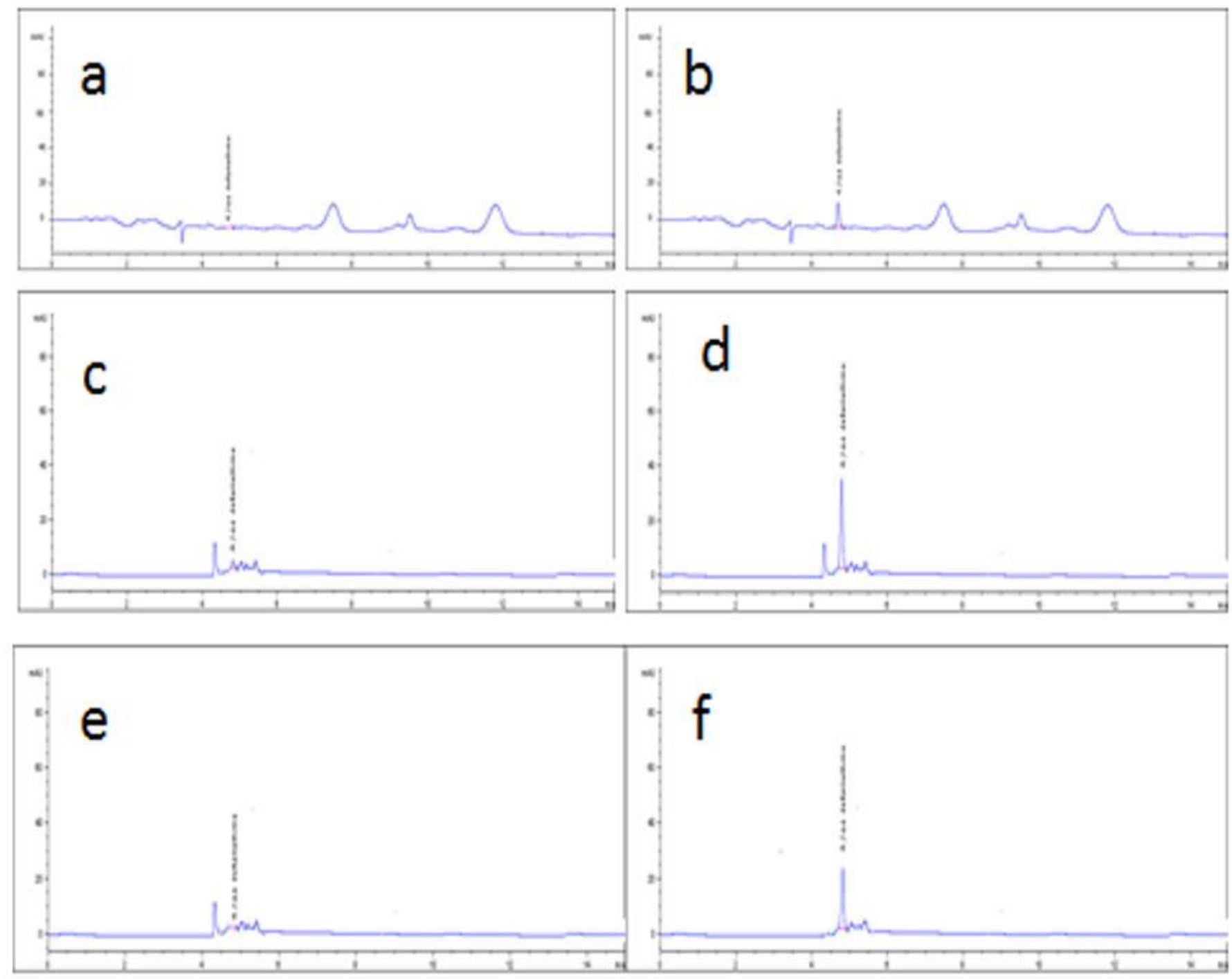

\section{Figure 1}

Bioremediation role of spirulina against Deltamethrin residues in meat, skin and liver using HPLC. Different levels of DM in chicken meat samples. A; DM+SP in muscle, b; DM muscle, c; DM+SP skin, d; DM skin, e; DM+SP liver, f; DM liver. 

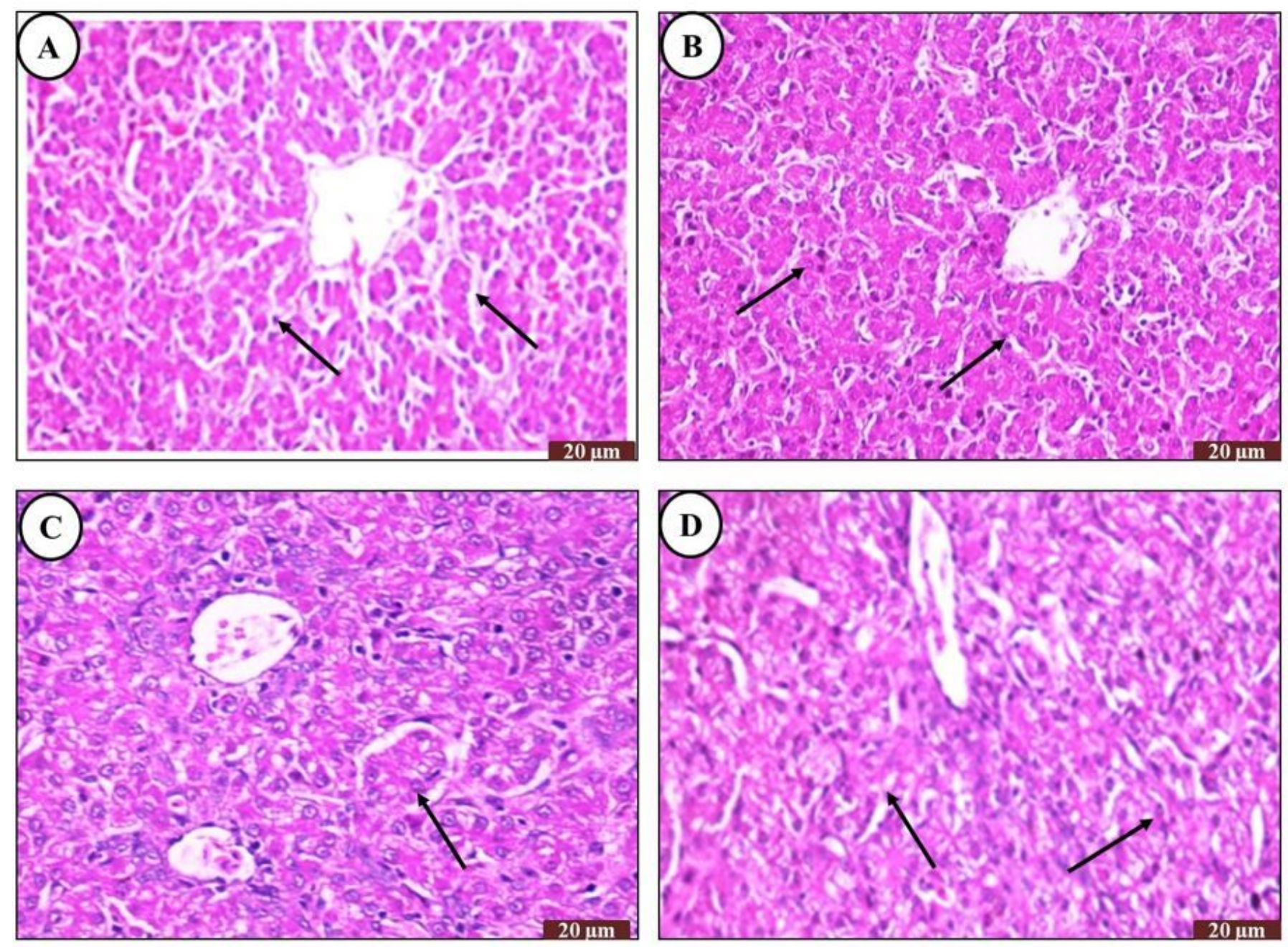

Figure 2

Photomicrograph of chiken's liver treated with DM and/or SP. A; control, B; SP, C: DM and D; DM+SP. 

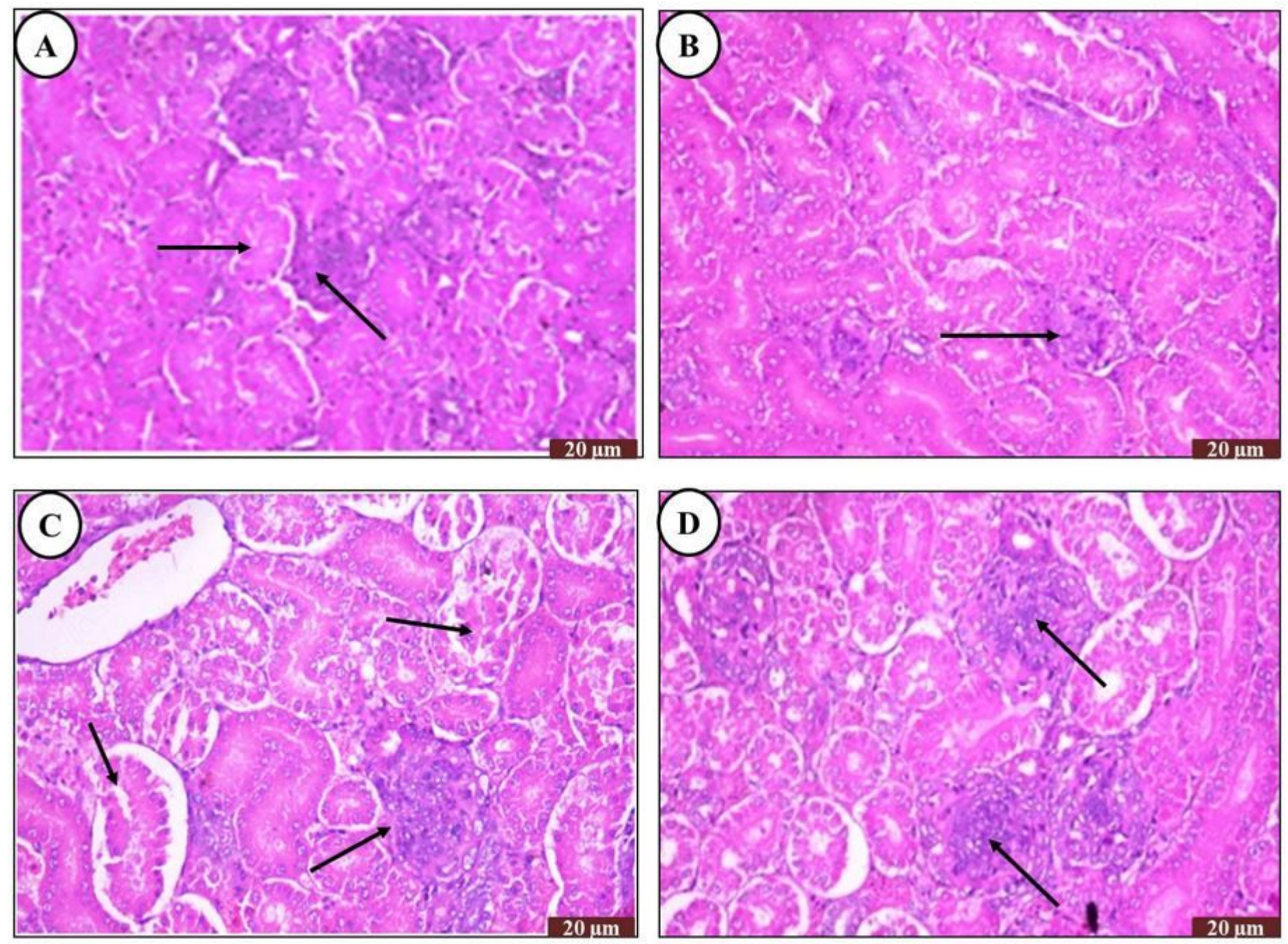

Figure 3

Photomicrograph of chiken's kidney treated with DM and/or SP. A; control, B; SP, C: DM and D; DM+SP. 

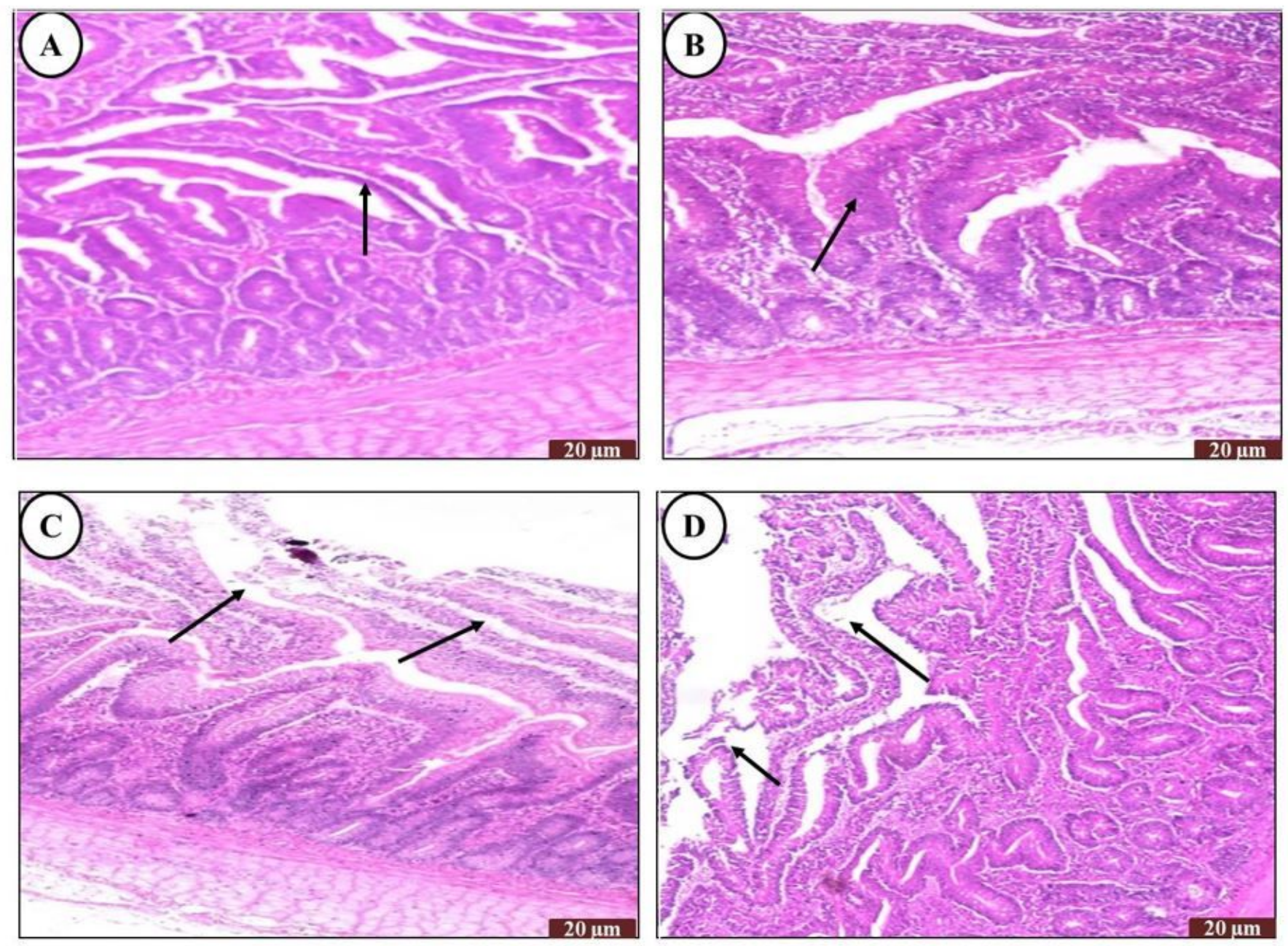

Figure 4

Photomicrograph of chiken's intestine treated with DM and/or SP. A; control, B; SP, C: DM and D; DM+SP. 